\title{
ANTIOXIDANT ACTIVITIES FROM VARIOUS EXTRACTS OF DIFFERENT PARTS OF KELAKAI (STENOCHLAENA PALUSTRIS) GROWN IN CENTRAL KALIMANTAN - INDONESIA
}

\author{
SITI KUSMARDIYANI, GRACE NOVITA, IRDA FIDRIANNY* \\ Pharmaceutical Biology Research Group, School of Pharmacy, Bandung Institute of Technology, Indonesia. \\ Email: irdafidrianny@gmail.com
}

Received: 23 June 2016, Revised and Accepted: 11 July 2016

\section{ABSTRACT}

Objectives: The aims of this research were to determine antioxidant activity from various extracts of different parts of kelakai (Stenochlaena palustris [Burm.f.] Bedd) using two antioxidant testing methods, which were 2,2-diphenyl-1-picrylhydrazyl (DPPH) and ferric reducing antioxidant power (FRAP), and correlation of total phenolic contents (TPC), total flavonoid contents (TFC), and total carotenoid contents (TCC) with their inhibitory concentration $50 \%\left(\mathrm{IC}_{50}\right)$ of DPPH and exhibitory concentration $50 \%\left(\mathrm{EC}_{50}\right)$ of FRAP.

Methods: Sample was extracted by reflux using different polarity solvents. The extracts were evaporated using vacuum rotary evaporator. Antioxidant activities were tested using DPPH and FRAP assays, determination of TPC, TFC, and TCC was carried out by ultraviolet-visible spectrophotometry, and correlation with their IC $_{50}$ of DPPH and EC $_{50}$ of FRAP capacities was analyzed by Pearson's method.

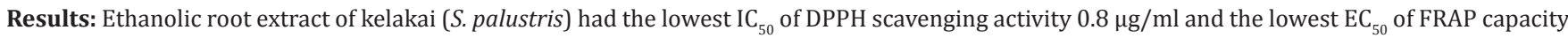
$5.4 \mu \mathrm{g} / \mathrm{ml}$. Ethanolic kelakai root extract demonstrated the highest phenolic content, ethyl acetate young leaves extract had the highest flavonoid content, and the highest carotenoid content was given by n-hexane root extract. There was significantly negative correlation between TPC in root extract of kelakai with their $\mathrm{IC}_{50}$ of DPPH and $\mathrm{EC}_{50}$ of FRAP.

Conclusions: All different extracts of kelakai parts were categorized as very strong antioxidants by DPPH method. Phenolic compounds in kelakai root extract were the major contributor in antioxidant activities by DPPH and FRAP methods. DPPH and FRAP showed linear results in antioxidant activities of root kelakai extract.

Keywords: Antioxidant, 2,2-diphenyl-1-picrylhydrazyl, Ferric reducing antioxidant power, Stenochlaena palustris, Young leaves, Old leaves, Root.

(C) 2016 The Authors. Published by Innovare Academic Sciences Pvt Ltd. This is an open access article under the CC BY license (http://creativecommons. org/licenses/by/4. 0/) DOI: http://dx.doi.org/10.22159/ajpcr.2016.v9s2.13630

\section{INTRODUCTION}

Phenolic compounds and flavonoids are commonly found in many plants, which have many effects such as antioxidant activity and antibacterial activity [1-4]. Phenolic, flavonoid, and carotenoid compounds might be having antioxidant activity [5]. Antioxidant has many benefits to prevent the excessive of free radical in oxidative stress which can cause many degenerative diseases. Consumption of fruits and vegetables can prevent negative effect of oxidative stress because they contain phenolic, flavonoid, and carotenoid compounds, which have antioxidant capacity [6]. Previous researches represented that total phenolic content (TPC) and total flavonoid content (TFC) could be correlated to their antioxidant activities [7-9]. Plants included sweet potatoes, guava, lemon grass, tea, and legumes contained phenolic and flavonoid compounds $[1-3,10,11]$.

Ferric reducing antioxidant power (FRAP), 2,2'-azino-bis (3-ethylbenzthiazoline-6-sulfonic acid (ABTS), and 2,2-diphenyl1-picrylhydrazyl (DPPH) methods could be used to observe antioxidant activity in many plants extracts $[4,10,11]$. The previous researches $[3,8,11,12]$ revealed that DPPH, ABTS, and FRAP can be performed to determine antioxidant activity of fruits, vegetables, and food. Kelakai (Stenochlaena palustris), empirically used in Central Kalimantan for antiaging, contained many derivates of kaempferol glycosides which can act as antioxidant [13]

The objectives of this research were to evaluate antioxidant activities in various polarity extracts (n-hexane, ethyl acetate, and ethanol) from different parts of kelakai grown in Central Kalimantan - Indonesia, using DPPH and FRAP assays and correlations of TPC, TFC, and total carotenoid content (TCC) with their antioxidant activities.

\section{METHODS}

\section{Materials}

DPPH, 2,4,6-tripyridyl-S-triazine (TPTZ), gallic acid, quercetin, and beta carotene were purchased from Sigma-Aldrich (MO, USA), different parts of kelakai (S. palustris). All of other reagents were analytical grades.

\section{Preparation of sample}

Different parts of kelakai (S. palustris), which were young leaves named as YL, old leaves as $\mathrm{OL}$, and roots as RO, were collected from Palangkaraya, Central Kalimantan - Indonesia, were thoroughly washed with tap water, sorted while wet, cut, dried, and grinded into powder.

\section{Extraction}

About 300 g of powdered samples were extracted by reflux using different polarity solvents. Extraction using n-hexane was repeated three times. The remaining residue was then extracted three times using ethyl acetate. Finally, the remaining residue was extracted three times using ethanol. Hence, totally there were nine extracts: Three n-hexane extracts (namely, YL1, OL1, and R01), three ethyl acetate extracts (YL2, OL2, and RO2), and three ethanolic extracts (YL3, OL3, and R03).

\section{Antioxidant activity by DPPH assay}

Antioxidant activity by DPPH assay was performed using modified Blois's method [14]. Various concentrations of each extract were pipetted into DPPH solution $50 \mu \mathrm{g} / \mathrm{ml}$ (volume 1:1) to initiate the reaction for obtaining a calibration curve. The absorbance was observed after 30 minutes incubation at wavelength $515 \mathrm{~nm}$ by ultravioletvisible (UV-VIS) spectrophotometer Hewlett Packard 8435. Methanol was used as a blank, DPPH solution $50 \mu \mathrm{g} / \mathrm{ml}$ as control and ascorbic 
acid as standard. Analysis was conducted in triplicate for standard and each extract. Antioxidant activity was determined by calculating the percentage of reduction of DPPH absorbance [15]. Inhibitory concentration $50 \%\left(\mathrm{IC}_{50}\right)$ of DPPH scavenging activity of each extract can be evaluated using its calibration curve.

\section{Antioxidant capacity by FRAP assay}

Preparation of FRAP solution was adopted from Benzi [16], which was prepared in acetate buffer $\mathrm{pH}$ 3.6. Each extract $50 \mu \mathrm{g} / \mathrm{ml}$ was added into FRAP solution $50 \mu \mathrm{g} / \mathrm{ml}(1: 1)$ to initiate the reaction. After 30 minutes incubation, the absorbance was measured at wavelength $593 \mathrm{~nm}$ using the UV-VIS spectrophotometer Hewlett Packard 8435 Acetate buffer was used as a blank, FRAP solution $50 \mu \mathrm{g} / \mathrm{ml}$ as control and ascorbic acid as standard. Analysis was performed in triplicate for standard and each extract. Antioxidant capacity was determined based on increasing in Fe (II)-TPTZ absorbance by calculating the percentage of antioxidant capacity [16]. Exhibitory concentration $50 \%\left(\mathrm{EC}_{50}\right)$ of FRAP capacity of each extract can be determined using its calibration curve.

\section{TPC}

TPC determination was carried out using Folin-Ciocalteu reagent [17]. The absorbance was seen at wavelength $765 \mathrm{~nm}$. Analysis was performed in triplicate for each extract. Standard solution of gallic acid $(55-175 \mu \mathrm{g} / \mathrm{ml})$ was used to obtain a calibration curve. TPC was exposed as the percentage of total gallic acid equivalent per $100 \mathrm{~g}$ extract (g GAE/100 g).

\section{TFC}

Chang's method [18] with minor modification was done in determining TFC. The absorbance was observed at wavelength $415 \mathrm{~nm}$. Analysis was conducted in triplicate for each extract. Quercetin solution 30-120 $\mu \mathrm{g} / \mathrm{ml}$ was used to obtain a calibration curve. TFC was reported as percentage of total quercetin equivalent per $100 \mathrm{~g}$ extract (g QE/100 g).

TCC

TCC was performed by modified Thaipong's method [11]. Each extract was diluted in $\mathrm{n}$-hexane [5]. The absorbance was measured at wavelength $470 \mathrm{~nm}$. Analysis was conducted in triplicate for each extract. Beta carotene solution $40-80 \mu \mathrm{g} / \mathrm{ml}$ was used to obtain a calibration curve. TCC was presented as percentage of total beta carotene equivalent per $100 \mathrm{~g}$ extract (g BE/100 g).

\section{Statistical analysis}

Each sample analysis was performed in triplicate. All of the presented results are means ( \pm standard deviation) of at least three independent experiments. Statistical analysis using ANOVA with a statistical significance level set at $\mathrm{p}<0.05$ and post-hoc Tukey procedure was carried out with SPSS 16 for Windows. Correlation between the TPC TFC, TCC, and antioxidant activities and correlation between two antioxidant activity methods were performed using the Pearson's method.

\section{RESULTS}

\section{Antioxidant activity by DPPH and FRAP assays}

Antioxidant activity in different extracts of kelakai parts by DPPH and FRAP assays was performed by determining $\mathrm{IC}_{50}$ of DPPH scavenging activities and $\mathrm{EC}_{50}$. $\mathrm{IC}_{50}$ of DPPH scavenging activities and $\mathrm{EC}_{50}$ of FRAP capacities of each extract were compared to $\mathrm{IC}_{50}$ or $\mathrm{EC}_{50}$ ascorbic acid as standard. The lowest value of $\mathrm{IC}_{50}$ or $\mathrm{EC}_{50}$ means the highest antioxidant activity.

\section{TPC in kelakai extracts}

TPC among different part extracts of kelakai was represented in term of GAE using the standard curve equation $y=0.005 x-0.016, R^{2}=0.987$. TPC in kelakai extracts had different results varied from 1.87 to $24.22 \mathrm{~g}$ GAE/100 g (Fig. 1). Ethanolic roots extract of kelakai (RO3) had the highest TPC (24.22 g GAE/100 g), and its n-hexane extract (R01) gave the lowest TPC $1.87 \mathrm{~g} \mathrm{GAE} / 100 \mathrm{~g}$.

\section{TFC in kelakai extracts}

TFC among different part extracts of kelakai were exhibited in term of $Q E$ using the standard curve equation $y=0.006 x+0.029, R^{2}=0.998$. TFC in kelakai extracts were in the range of 1.99-20.93 g QE/100 g. The highest TFC (20.93 g QE/100 g) was denoted by ethyl acetate YLs extract of kelakai (YL2), and the lowest TFC given by its ethanolic extract (YL3) (Fig. 2).

\section{TCC in kelakai extracts}

TCC in different part extracts of kelakai were demonstrated in term of beta carotene equivalent using the standard curve equation $y=0.012 x-0.178, R^{2}=0.981$. TCC in different extracts of kelakai parts ranged from 7.28 to $38.49 \mathrm{~g} \mathrm{BE} / 100 \mathrm{~g}$. N-hexane root extract of kelakai (RO1) revealed the highest TCC $(38.49 \mathrm{~g} \mathrm{BE} / 100 \mathrm{~g})$, whereas the lowest carotenoid content $(7.28 \mathrm{~g} \mathrm{BE} / 100 \mathrm{~g})$ was shown by ethanolic YLs extract of kelakai (YL3) (Fig. 3).

Correlations between TPC, TFC, TCC in kelakai extracts and IC $_{50}$ of DPPH scavenging activities, $\mathrm{EC}_{50}$ of FRAP capacities

TPC in YLs and root extracts of kelakai had significant and negative correlation with their $\mathrm{IC}_{50}$ of DPPH scavenging activities $(\mathrm{r}=-0.695$, $\mathrm{p}<0.05 ; \mathrm{r}=-0.818, \mathrm{p}<0.01$, respectively), and TPC in OL and root extracts of kelakai gave negative and significant correlation with their $\mathrm{EC}_{50}$ FRAP capacities ( $\mathrm{r}=-0.991, \mathrm{r}=-0.839, \mathrm{p}<0.01$, respectively) (Table 1 ).

\section{DISCUSSION}

The previous researches $[19,20]$ revealed that kelakai (S. palustris) had antioxidant capacity. There was no research regarding the antioxidant activity of different parts of kelakai (S. palustris), which were YLs, OL, and root extracted using increasing polarity solvents (n-hexane, ethyl acetate, and ethanol) and tested by DPPH and FRAP assays.

Antioxidant will transfer the hydrogen to DPPH and DPPH will stable. DPPH free radicals dissolved in methanol give absorption at wavelength $516 \mathrm{~nm}$. Colors of DPPH would be changed from purple to yellow when the free radicals were scavenged by antioxidant [21]. FRAP reagent is ferric (III) chloride which was combined with TPTZ in acetate buffer

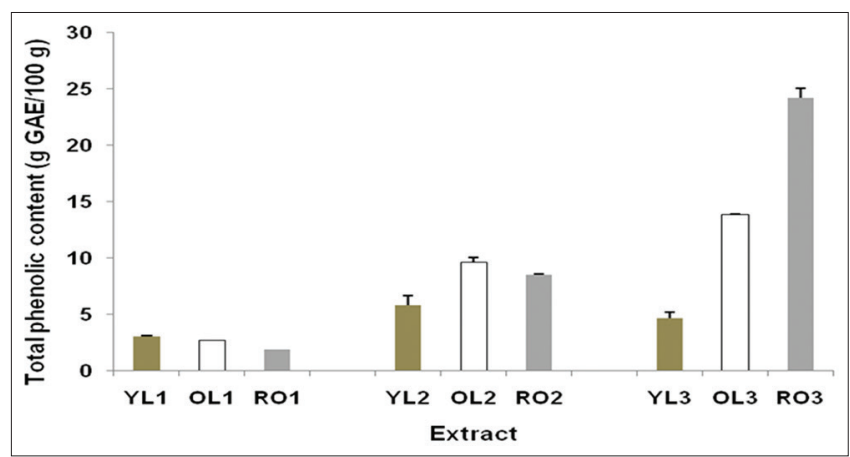

Fig.1: Total phenolic content in kelakai extracts, $n=3$

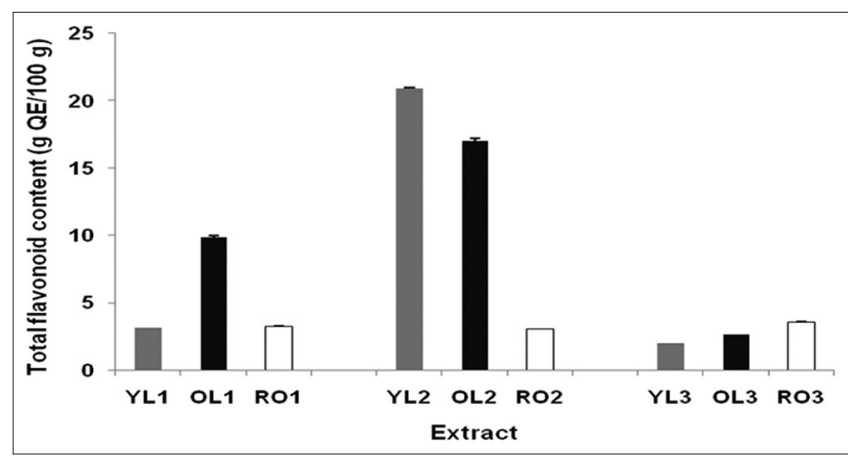

Fig. 2: Total flavonoid content in kelakai extracts, $n=3$ 
Table 1: Pearson's correlation coefficient of TPC, flavonoid, carotenoid content in different parts extracts of kelakai parts with their IC $_{50}$ of DPPH scavenging activities and $\mathrm{EC}_{50}$ of FRAP capacities

\begin{tabular}{|c|c|c|c|c|c|c|}
\hline \multirow[t]{2}{*}{ Antioxidant parameter } & \multicolumn{6}{|c|}{ Pearson's correlation coefficient (r) } \\
\hline & TPC & TFC & TCC & EC $_{50}$ FRAP YL & $\mathrm{EC}_{50}$ FRAP OL & $\mathrm{EC}_{50}$ FRAP RO \\
\hline $\mathrm{IC}_{50}$ DPPH YL & $-0.695^{*}$ & $-0.992^{* *}$ & $-0.991^{* *}$ & $0.879^{* *}$ & & \\
\hline $\mathrm{IC}_{50}^{50} \mathrm{DPPH} \mathrm{OL}$ & $0.858^{* *}$ & $0.105 \mathrm{~ns}$ & $-0.129 \mathrm{~ns}$ & & $-0.888^{* *}$ & \\
\hline $\mathrm{IC}_{50}^{\mathrm{s0}} \mathrm{DPPH} \mathrm{RO}$ & $-0.818^{* *}$ & $-0.320 \mathrm{~ns}$ & $0.980^{* *}$ & & & $0.996^{* *}$ \\
\hline $\mathrm{EC}_{50}^{50}$ FRAP YL & $-0.328 \mathrm{~ns}$ & $-0.863^{* *}$ & $-0.916^{* *}$ & & & \\
\hline $\mathrm{EC}_{50}^{50}$ FRAP OL & $-0.991^{* *}$ & $0.312 \mathrm{~ns}$ & $0.527 \mathrm{~ns}$ & & & \\
\hline $\mathrm{EC}_{50}^{50}$ FRAP RO & $-0.839 * *$ & $-0.345 \mathrm{~ns}$ & $0.989 * *$ & & & \\
\hline
\end{tabular}

*Significant at $\mathrm{p}<0.05$, $^{*}$ Significant at $\mathrm{p}<0.01$. IC $\mathrm{IC}_{50}$ DPPH= $\mathrm{IC}_{50}$ DPPH scavenging activity, $\mathrm{EC}_{50}$ FRAP=EC $\mathrm{ERAP}_{50}$ capacity, YL: Young leaves of kelakai, OL: Old leaves of kelakai, RO: Root of kelakai, TPC: Total phenolic content, TFC: Total flavonoid content, TCC: Total carotenoid content, NS: Not significant, EC ${ }_{50}$ : Exhibitory concentration 50\%, FRAP: Ferric reducing antioxidant power, DPPH: 2,2-diphenyl-1-picrylhydrazyl, IC $_{50}$ : Inhibitory concentration $50 \%$

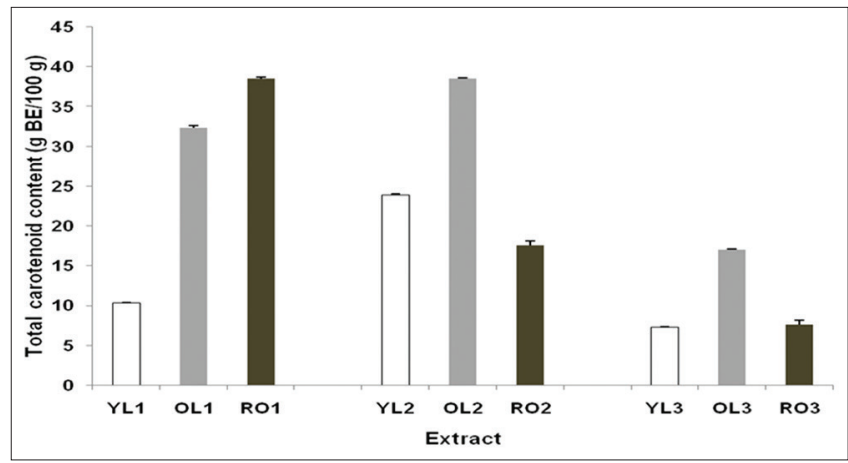

Fig. 3: Total carotenoid content in kelakai extracts, $n=3$

pH 3.6. Reduction potential of Fe (III)/Fe (II) is $0.77 \mathrm{~V}$. Antioxidant will reduce Fe (III) to Fe (II) if it has reduction potential lower than 0.77 V. Complex of Fe (II) - TPTZ shows blue and gave characteristic absorption at wavelength $593 \mathrm{~nm}$. Intensity of blue depends on amount of Fe (III) which is reduced to Fe (II) and form complex with TPTZ. $\mathrm{IC}_{50}$ of DPPH scavenging activities and $\mathrm{EC}_{50}$ of FRAP capacities in different parts of kelakai can be seen in Figs. 4 and 5 . The $\mathrm{IC}_{50}$ of DPPH scavenging activities and $\mathrm{EC}_{50}$ of FRAP capacities in different parts extracts of kelakai were compared to $\mathrm{IC}_{50}$ or $\mathrm{EC}_{50}$ of ascorbic acid standard. The lowest value of $\mathrm{IC}_{50}$ or $\mathrm{EC}_{50}$ means the highest antioxidant activity. Sample, which had an $\mathrm{IC}_{50}$ or $\mathrm{EC}_{50}$ lower than $50 \mu \mathrm{g} / \mathrm{ml}$, was a very strong antioxidant, $50-100 \mu \mathrm{g} / \mathrm{ml}$ was a strong antioxidant, and $101-150 \mu \mathrm{g} / \mathrm{ml}$ was a medium antioxidant while a weak antioxidant with $\mathrm{IC}_{50}$ or $\mathrm{EC}_{50}>150 \mu \mathrm{g} / \mathrm{ml}[14]$.

In the present research, antioxidant activities by DPPH method were represented by $\mathrm{IC}_{50}$ of DPPH. $\mathrm{IC}_{50}$ means the concentration of extract (antioxidant sample) that can scavenge free radical DPPH 50\% and figured by decreasing absorbance of DPPH after adding extract. IC $_{50}$ of DPPH can be calculated using regression linear equation of calibration curve of each extract.

Moreover, antioxidant activities can be expressed by the percentage of DPPH scavenging activity, by reacting DPPH $50 \mu \mathrm{g} / \mathrm{ml}$ and sample 50 $\mu \mathrm{g} / \mathrm{ml}$. The result was compared to the percentage of DPPH scavenging activity of ascorbic acid, by adding DPPH $50 \mu \mathrm{g} / \mathrm{ml}$ and ascorbic acid $50 \mu \mathrm{g} / \mathrm{ml}$. The value of the percentage of DPPH scavenging activity of ascorbic acid did not achieve 100\% because there was still residual yellow in solution after giving hydrogen atom to DPPH by antioxidant in sample extract $[22,23]$. The percentage of DPPH scavenging activity could not present the real antioxidant activities. Antioxidant activity can be stated in percentage of DPPH scavenging activity, which was performed normally by adding extract with one concentration $50 \mu \mathrm{g} / \mathrm{ml}$ only to DPPH solution $50 \mu \mathrm{g} / \mathrm{ml}$ (volume 1:1). If extract $50 \mu \mathrm{g} / \mathrm{ml}$ can scavenge DPPH $50 \mu \mathrm{g} / \mathrm{ml} 57 \%$, its not means extract $60 \mu \mathrm{g} / \mathrm{ml}$ will always scavenge DPPH more than $57 \%$. The extract $60 \mu \mathrm{g} / \mathrm{ml}$ will present the percentage of DPPH may be $>57 \%$ or lower than $57 \%$. It is due to extract consisted

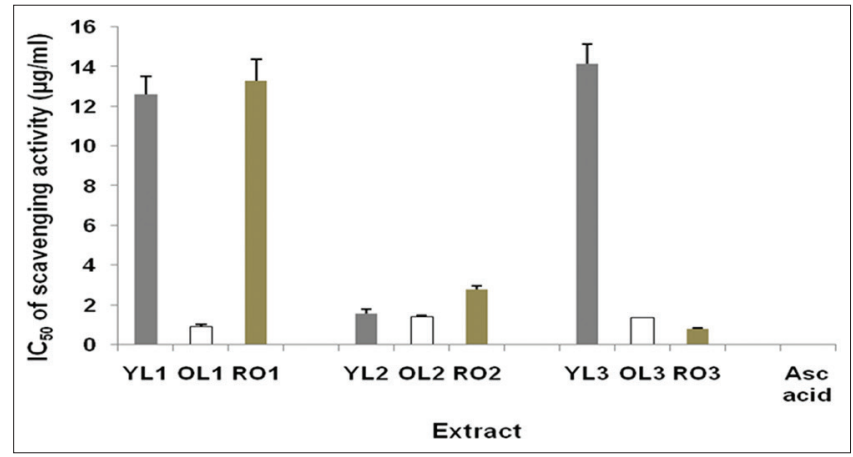

Fig. 4: Inhibitory concentration $50 \%$ of 2,2-diphenyl-1picrylhydrazyl in different extracts of kelakai parts, $n=3$

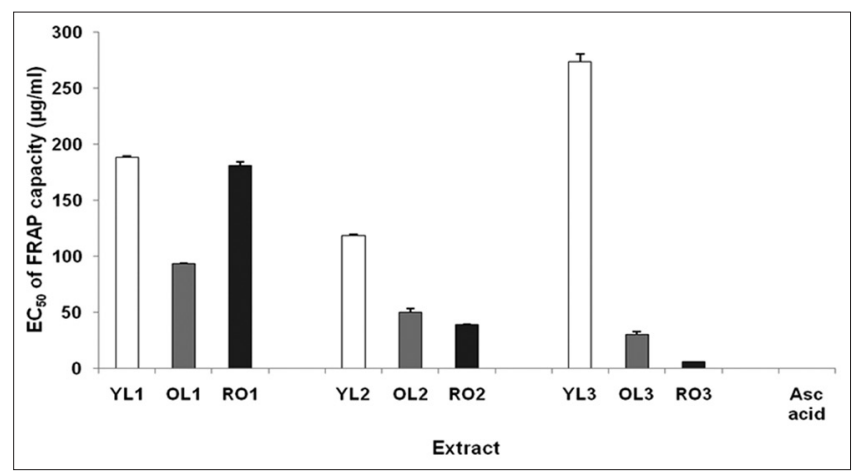

Fig. 5: Exhibitory concentration $50 \%$ of ferric reducing antioxidant power capacities in different extracts of kelakai parts, $n=3$

of many compounds and not all compounds in extract have antioxidant activities, may be some of them act as antagonist of antioxidant. In extract $50 \mu \mathrm{g} / \mathrm{ml}$, the compounds, which can act as antagonist antioxidant, have not achieved yet its effective concentration. Therefore, the antioxidant components can scavenge DPPH 57\%. In extract $60 \mu \mathrm{g} /$ $\mathrm{ml}$, the antagonist of antioxidant components have achieved its effective concentration, and it will reduce the ability of antioxidant components, therefore, extract $60 \mu \mathrm{g} / \mathrm{ml}$ will give percentage of DPPH lower than $57 \%$. Antioxidant activity can be stated as $\mathrm{IC}_{50}$. For calculating $\mathrm{IC}_{50}$ of DPPH should be used many concentrations of extract which shown linear decreasing in absorbance of DPPH. Based on the results, the regression linear equation of calibration curve of each extract can be assessed. After determining regression linear equation, value of $\mathrm{IC}_{50}$ of DPPH can be calculated. Based on the explanation above, it can be seen that the percentage of DPPH scavenging activities will not represent the real antioxidant activities; however, the real of antioxidant activities will be exposed by $\mathrm{IC}_{50}$ of DPPH value. 
Antioxidant capacities by FRAP assay were exposed by $\mathrm{EC}_{50}$ of FRAP capacity. $\mathrm{EC}_{50}$ is concentration of antioxidant sample that can increase FRAP capacity $50 \%$ and stated by increasing absorbance of complex of Fe (II) - TPTZ after adding antioxidant sample. Regression linear equation of calibration curve of each extract can be used to determine $\mathrm{EC}_{50}$ of FRAP.

The present study exposed that all of different parts (YL, OL and root) extracts of kelakai (S. palustris) had $\mathrm{IC}_{50}$ of DPPH varied from 0.8 to $14.13 \mu \mathrm{g} / \mathrm{ml}$, and it means their antioxidant by DPPH assay can be classified as a very strong antioxidant because lower than $50 \mu \mathrm{g} / \mathrm{ml}$. The highest antioxidant was exposed by ethanolic root extract of kelakai (IC of DPPH $0.8 \mu \mathrm{g} / \mathrm{ml}$ ), meanwhile IC I0 $_{50}$ of DPPH ascorbic acid $0.14 \mu \mathrm{g} / \mathrm{ml}$. It can be conclude that antioxidant potency of ascorbic acid was around six-fold potency of ethanolic root extract of kelakai. Research by Chai [19] reported that water extract of mature sterile frond of S. palustris $150 \mathrm{mg} / \mathrm{ml}$ showed the highest percentage of DPPH radical scavenging activity (95\%) compared to young sterile frond, young fertile frond, and mature fertile frond, while Trolox $50 \mu \mathrm{g} / \mathrm{ml}$ can scavenge DPPH around $99 \%$. The present study stated that ethanolic extract of YL, OL and root of kelakai (S. palustris) were $14.13,1.38$, and $0.8 \mu \mathrm{g} / \mathrm{ml}$, respectively.

A previous study revealed that percentage of hydroxyl radical scavenging activity of kelakai leaves $(16.60 \%)$ was similar to ascorbic acid $(16.43 \%)$. It was linear with its percentage hydrogen peroxide scavenging activity $60.10 \%$, ascorbic acid $60.10 \%$, its percentage of chelating effect on ferrous ions $27.64 \%$, ascorbic acid $26.68 \%$. Based on this result, antioxidant activity of kelakai leaves was similar to ascorbic acid using percentage of hydroxyl radical scavenging activity, percentage hydrogen peroxide scavenging activity, and percentage of chelating effect on ferrous ions [20]. The other research expressed that mature sterile frond of kelakai with concentration of $500 \mu \mathrm{g} / \mathrm{ml}$ had the highest FRAP value (72.36 $\mathrm{mM} \mathrm{Fe}^{2+}$ equivalents) compared to its young fertile frond (45.07 mM Fe${ }^{2+}$ equivalents), young sterile frond (41.92 $\mathrm{mM} \mathrm{Fe}^{2+}$ equivalents), and mature fertile frond (20.99 $\mathrm{m} \mathrm{M} \mathrm{Fe}^{2+}$ equivalents) [19] It was different from the present research which demonstrated that FRAP capacity of different parts of kelakai ranged from 5.4 to 273.34 $\mu \mathrm{g} / \mathrm{ml}$. The highest antioxidant capacity by FRAP assay was shown by ethanolic root extract of kelakai which had the lowest $\mathrm{EC}_{50}$ of FRAP (5.4 $\mu \mathrm{g} / \mathrm{ml}$ ), whereas $\mathrm{EC}_{50}$ of FRAP capacity of ascorbic acid was $3.36 \mu \mathrm{g} / \mathrm{ml}$. It can be concluded that antioxidant potency of ascorbic acid was 1.5fold potency of ethanolic root extract of kelakai by FRAP assay.

TPC, TFC, and TCC might have the antioxidant capacity [5]. Antioxidant activity can be related with the TPC $[24,25]$. Previous research by Chear et al. [13] revealed that TPC in methanolic extract of young frond and mature frond of kelakai were 9.415 and $25.2 \mathrm{~g} \mathrm{GAE} / 100 \mathrm{~g}$, respectively. TPC in water extracts of young sterile frond, mature sterile frond, young fertile frond, and mature fertile frond were 4.258, 5.169, 4.168, and $1.878 \mathrm{~g} \mathrm{GAE} / 100 \mathrm{~g}$, respectively [19]. It was similar to the present study which demonstrated that ethanolic YL extract of kelakai gave TPC $4.67 \mathrm{~g}$ GAE$/ 100 \mathrm{~g}$ but different from ethanolic OL and root extracts of kelakai (13.83 and $24.22 \mathrm{~g} \mathrm{GAE} / 100 \mathrm{~g}$, respectively).

TFC in methanolic extract of mature frond of kelakai $(50.356 \mathrm{~g} Q \mathrm{E} / 100 \mathrm{~g})$ was higher than young frond (20.566 g QE/100 g) [13]. It was contrary to the present study which exposed that TFC in ethanolic extract of YLs, OLs, and root extract of kelakai were 1.99, 2.63, and $3.55 \mathrm{~g} \mathrm{QE} / 100 \mathrm{~g}$ respectively, meanwhile TCC in ethanolic extract of YLs, OLs, and root extracts of kelakai were $7.28,17.03$, and $7.61 \mathrm{~g} \mathrm{BE} / 100 \mathrm{~g}$, respectively. The previous research stated that TFC in water extract of mature sterile frond of kelakai (5.805 g catechin equivalent [CE]/100 g) was higher than TFC in water extract of young fertile frond, young sterile frond, and mature fertile frond of kelakai $(5.721,4.659$, and $1.895 \mathrm{~g} \mathrm{CE} / 100 \mathrm{~g}$, respectively). Study by Chai et al. [19] also expressed total anthocyanin content. The water extract of young sterile frond of kelakai contained the highest total anthocyanin content which was 51.32 mg cyanidin-3glucoside equivalent (C3GE)/100 g compared to mature sterile frond ( $2.56 \mathrm{mg} \mathrm{C} 3 \mathrm{GE} / 100 \mathrm{~g}$ ), young fertile frond $92.67 \mathrm{mg} \mathrm{C} 3 \mathrm{GE} / 100 \mathrm{~g}$ ), and mature fertile frond $(2.67 \mathrm{mg} \mathrm{C} 3 \mathrm{GE} / 100 \mathrm{~g})$, meanwhile TFC in kelakai leaves extract was $14.5 \mu \mathrm{g} \mathrm{QE} / \mathrm{ml}[20]$.

Coefficient of Pearson correlation was significantly negative if $-0.61 \leq r \leq-0.97$ and significantly positive if $0.61 \leq r \leq 0.97$ [11]. The highest antioxidant activity was expressed by the lowest $\mathrm{IC}_{50}$ of DPPH scavenging activity and $\mathrm{EC}_{50}$ of FRAP capacity. It means increasing in TFC, TPC, and TCC caused increasing in antioxidant activities, which was stated by lower $\mathrm{IC}_{50}$ of DPPH scavenging activity and or $\mathrm{EC}_{50}$ of FRAP capacity. Therefore, the good correlation between TPC, TFC, and TCC with $\mathrm{IC}_{50}$ of DPPH or $\mathrm{EC}_{50}$ of FRAP was significant and negative correlation [5]. The present study showed that TPC in kelakai root extract had significant and negative correlation with their $\mathrm{IC}_{50}$ of DPPH $(\mathrm{r}=-0.818, \mathrm{p}<0.01)$ and $\mathrm{EC}_{50}$ of FRAP $(\mathrm{r}=-0.839, \mathrm{p}<0.01)$. Previous research [19] assessed the correlation between TPC and percentage of radical scavenging activities, also with FRAP values which were presented in $\mathrm{mM} \mathrm{Fe}^{2+}$ equivalent. Therefore, the good correlation was a positive and significant correlation. It means increasing in TPC will increase the percentage of radical scavenging activities and FRAP values. The research denoted that TPC in water extract of young sterile frond, mature sterile frond, young fertile frond, and mature fertile frond extract of kelakai showed significant and positive correlation with their percentage of radical scavenging activities $\left(R^{2}=0.968, p<0.05\right)$ and FRAP values $\left(R^{2}=0.960, p<0.05\right)$. The present study also exhibited that $\mathrm{IC}_{50}$ of DPPH of YLs and root extracts of kelakai was positive and significant with their $\mathrm{EC}_{50}$ of FRAP ( $\mathrm{r}=0.879 ; \mathrm{r}=0.996, \mathrm{p}<0.01$, respectively). It means antioxidant activity of YLs and root extracts of kelakai (S. palustris) were linear in DPPH and FRAP assays.

Flavonoids, tannins, and phenolic acids are included in phenolic groups. Cinamic acid has higher antioxidant than benzoic acid [26]. Ortho and para hydroxyl substitution have stronger antioxidant capacity [27] TPC in ethyl acetate OL extract of kelakai (OL2) $9.62 \mathrm{~g} \mathrm{GAE} / 100 \mathrm{~g}$ was lower than TPC in ethanolic OL extract (OL3) $13.83 \mathrm{~g} \mathrm{GAE} / 100 \mathrm{~g}$, whereas IC $_{50}$ of DPPH of OL2 $1.43 \mu \mathrm{g} / \mathrm{ml}$ was similar to IC I0 $_{50}$ of DPPH of OL3 $1.38 \mu \mathrm{g} / \mathrm{ml}$. It can be suggested that OL3 contained many phenolic compounds which had low antioxidant activity and only little amount with high antioxidant activity, whereas OL2 consisted of many phenolic compounds which had high antioxidant activity.

Flavonoid compound will be included in phenolic groups which have $\mathrm{OH}$ in A ring and or $\mathrm{B}$ ring. The flavonoid aglycones had higher antioxidant activity than flavonoid glycosides. Flavonoid will show high antioxidant activity if has ortho di- $\mathrm{OH}$ at $\mathrm{C}-3^{\prime}-\mathrm{C} 4^{\prime}, \mathrm{OH}$ at $\mathrm{C}-3$, oxo function at $\mathrm{C}-4$, and double bond at $\mathrm{C}-2$ and $\mathrm{C}-3$. The ortho di-OH position at C-3'-C-4' had the highest influence to antioxidant activity of flavonoid [26]. Study by Chear et al. [13] reported that mature sterile frond of $S$. palustris contained kaempferol glycosides. In Fig. 2, it can be seen TFC in n-hexane root extract of kelakai (RO1) $3.23 \mathrm{~g} \mathrm{QE} / 100 \mathrm{~g}$ was similar to TFC in ethanolic root extract (RO3) $3.55 \mathrm{~g} / \mathrm{QE} / 100 \mathrm{~g}$, but R03 had higher antioxidant activity which stated by lower IC ${ }_{50}$ of DPPH of RO3 $(0.8 \mu \mathrm{g} / \mathrm{ml})$ than R01 $(13.3 \mu \mathrm{g} / \mathrm{ml})$. Flavonoids, which soluble in n-hexane, are high methoxylated flavonoid, high acetylated flavonoid, flavan, and flavanon. It can be suggested that many flavonoid compounds in R01 were the flavonoid which had low antioxidant activity, with $\mathrm{OH}$ at position in C-3' only, or $\mathrm{OH}$ at C-4' only, or flavanon, or without oxo function at $\mathrm{C}-4$, or without free $\mathrm{OH}$ at $\mathrm{C}-3$. Meanwhile, many flavonoid compounds in R03 were flavonoid with high antioxidant activity. The kaempferol glycoside is soluble in ethanol, but its antioxidant activity is lower than quercetin glycoside because kaempferol glycoside does not contain $\mathrm{OH}$ at the highest influence antioxidant activity in flavonoid which is ortho di-OH at C-3'-C-4'.

Carotenoid compounds have the antioxidant capacity by scavenging free radical [28] and more double bonds in carotenoid will give higher scavenging free radical activity. Beta carotene was used as standard because it has conjugation double bonds which have ability to scavenge free radicals [29]. TCC in n-hexane YL extract of kelakai (YL1) $10.32 \mathrm{~g}$ $\mathrm{BE} / 100 \mathrm{~g}$ was lower than TCC in $\mathrm{n}$-hexane root extract (RO1) $38.49 \mathrm{~g}$ 
BE/100 g; however, IC F0 $_{50}$ of DPPH of YL1 $(12.63 \mu \mathrm{g} / \mathrm{ml})$ was similar to $\mathrm{IC}_{50}$ of DPPH of RO1 $(13.3 \mu \mathrm{g} / \mathrm{ml})$. Increasing in lipophilicity of carotenoid would increase antioxidant activity which was revealed by lower IC I0 $_{50}$ of DPPH scavenging activity [30]. Research by Beutner et al. [31] reported that a carotenoid had $>7$ double bonds would give higher scavenging radical activity. Based on the results above, it can be predicted that many carotenoid compounds in YL1 had more than 7 double bonds which had high antioxidant activity, whereas in R01 had maximum 7 double bonds.

In FRAP assay, a compound will act as antioxidant if it has reduction potential lower than $0.77 \mathrm{~V}$ because reduction potential of $\mathrm{Fe}(\mathrm{III}) / \mathrm{Fe}(\mathrm{II})$ is $0.77 \mathrm{~V}$. A sample will have high antioxidant activity in FRAP assay if it contain many compound with reduction potential lower than $0.77 \mathrm{~V}$ TFC in n-hexane root extract of kelakai (RO1) $3.23 \mathrm{~g} \mathrm{QE} / 100 \mathrm{~g}$ was similar to TFC in ethanolic root extract (RO3) $3.55 \mathrm{~g} \mathrm{QE} / 100 \mathrm{~g}$, while $\mathrm{EC}_{50}$ of FRAP of R03 $5.4 \mu \mathrm{g} / \mathrm{ml}$ which was categorized as very strong antioxidant, was lower than $\mathrm{EC}_{50}$ of FRAP of R01 $180.58 \mu \mathrm{g} / \mathrm{ml}$ as weak antioxidant. It can be predicted that many flavonoid compounds in R03 have reduction potential lower than $0.77 \mathrm{~V}$; therefore, it reduced Fe (III) to Fe(II) then the Fe(II) formed blue complex with TPTZ and gave a blue, meanwhile many flavonoid compounds in R01 have reduction potential $>0.77 \mathrm{~V}$.

\section{CONCLUSION}

Different methods in parallel should be used to evaluate antioxidant activity of samples, due to the possibility of different results given by various methods. All different extracts of kelakai (S. palustris) parts were very strong antioxidant using DPPH assay. TPC in root extracts of kelakai had significantly negative correlation with their IC $_{50}$ of $\mathrm{DPPH}$ scavenging activities and $\mathrm{EC}_{50}$ of FRAP capacities. Phenolic compounds in root extracts of kelakai were the major contributor in their antioxidant activity by DPPH and FRAP methods. There was linear correlation between $\mathrm{IC}_{50}$ of DPPH scavenging activities and $\mathrm{EC}_{50}$ of FRAP capacities in YL and root extracts of kelakai. YL, OL and root of kelakai (S. palustris) have many benefits to prevent oxidative stress and potential as sources of natural antioxidant for further exploitation.

\section{REFERENCES}

1. Cheel J, Theoduloz C, Rodríguez J, Schmeda-Hirschmann G. Free radical scavengers and antioxidants from lemongrass (Cymbopogon citratus (dc.) Stapf.). J Agric Food Chem 2005;53(7):2511-7.

2. Zielinski AA, Haminiuk CW, Alberti A, Nogueira A, Demiate IM, Granato D. A comparative study of the phenolic compounds and the in vitro antioxidant activity of different Brazilian teas using multivariate statistical techniques. Food Res Int 2014;60:246-54.

3. Sebei K, Gnouma A, Herchi W, Sakouhi F, Boukhchina S. Lipids, proteins, phenolic composition, antioxidant and antibacterial activities of seeds of peanuts (Arachis hypogaea L) cultivated in Tunisia. Biol Res 2013;46(3):257-63.

4. Mokbel MS, Hashinaga F. Antibacterial and antioxidant activities of banana (Musa, AAA cv. Cavendish) fruits peel. Am J Biochem Biotechnol 2005;1(3):125-31.

5. Fidrianny I, Johan Y, Sukrasno. Antioxidant activities of different polarity extracts from three organs of makrut lime (Citrus hystrix dc) and correlation with total flavonoid, phenolic, carotenoid content. Asian J Pharm Clin Res 2015;8(4):239-43.

6. Gramza-Michalowska A, Czlapka-Matyasik M. Evaluation of the antiradical potential of fruit and vegetable snacks. Acta Sci Pol Technol Aliment 2011;10(1):63-72.

7. Mongkolsilp S, Pongbupakit I, Sae-Lee N, Sitthithaworn W. Radical scavenging activity and total phenolic content of medicinal plants used in primary health care. SWU J Pharm Sci 2004;9(1):32-5.
8. Xu BJ, Chang SK. Total phenolic content and antioxidant properties of eclipse black beans (Phaseolus vulgaris L.) As affected by processing methods. J Food Sci 2008;73(2):H19-27.

9. Mashkor IM. Phenolic content and antioxidant activity of fenugreek seeds extract. Int J Pharmacogn Phytochem Res 2014;6(4):841-4.

10. Fidrianny I, Windyaswari AS, Wirasutisna KR. Antioxidant capacities of various leaves extract from five colors varieties of sweet potatoes tubers using ABTS, DPPH assays and correlation with total flavonoid, phenolic, carotenoid content. Res J Med Plant 2013;7(3):130-40.

11. Thaipong K, Boonprakob U, Crosby K, Zevallos LC, Byrne DH. Comparison of ABTS, DPPH, FRAP, and ORAC assays for estimating antioxidant activity from guava fruit extracts. J Food Compost Anal 2006;19(6):669-75.

12. Pellegrini N, Serafini M, Colombi B, Rio DD, Salvatore S. Total antioxidant capacity of plant food, beverages and oils consumed in Italy assessed by three different in vitro assays. J Am Coll Nutr 2003;133(9):2812-9.

13. Chear NJ, Khaw KY, Murugaiyah V, Lai CS. Cholinesterase inhibitory activity and chemical constituents of Stenochlaena palustris fronds at two different stages of maturity. J Food Drug Anal 2016;24:358-66.

14. Blois MS. Antioxidant determination by the use of stable free radicals. Nature 1958;181(4617):1199-2000.

15. Bedawey AA. Characteristics of antioxidant isolated from some plants sources. Shibin El-Kom, Cairo: Shibin El-Kom; 2010. p. 1-11.

16. Benzi IF, Strain JJ. The ferric reducing ability of plasma (FRAP) as a measure of "antioxidant power": The FRAP assay. Anal Biochem 1996;239(1):70-6.

17. Pourmorad F, Hosseinimehr SJ, Shahabimajd N. Antioxidant activity, phenol and flavonoid content of some selected Iranian medicinal plants. Afr J Biotechnol 2006;5(11):1142-5

18. Chang CC, Yang MH, Wen HM, Chern JC. Estimation of total flavonoid content in propolis by two complementary colorimetric methods. J Food Drug Anal 2002;10:178-82.

19. Chai TT, Panirchellvum E, Ong HC, Wong FC. Phenolic contents and antioxidant properties of Stenochlaena palustris, an edible medicinal fern. Bot Stud 2012;53:439-46.

20. Suhartono E, Viani E, Rahmadhan MA, Gultom IS, Rakhman MF, Indrawardhana D. Total flavonoid and antioxidant activity of some selected medicinal plants in South Kalimantan of Indonesian. APCBEE Procedia 2012;4:235-9.

21. Li XC, Wang XZ, Chen DF, Chen SZ. Antioxidant activity and mechanism of protochatechuic acid in vitro. J Funct Food Health Dis 2011;1(7):232-44.

22. Barreira JC, Ferreira IC, Oliveira MB, Pereira JA. Effects of different phenols extraction conditions on antioxidant activity of almond (Prunus dulcis) fruits. J Food Biochem 2009;33(6):763-76.

23. Miliauskas G, Venskutonis PR, van Beek TA. Screening of radical scavenging activity of some medicinal and aromatic plant extracts. Food Chem 2004;85(2):231-7.

24. Pandey KB, Rizvi SI. Plant polyphenols as dietary antioxidants in human health and disease. Oxid Med Cell Longev 2009;2(5):270-8.

25. Kondratyuk T, Pezzuto J. Natural product polyphenols of relevance to human health. Pharm Biol 2004;42(1):46-63.

26. Heim KE, Tagliaferro AR, Bobilya DJ. Flavonoid antioxidants: Chemistry, metabolism and structure-activity relationships. J Nutr Biochem 2002;13(10):572-84.

27. Sroka Z, Cisowski W. Hydrogen peroxide scavenging, antioxidant and anti-radical activity of some phenolic acids. Food Chem Toxicol 2003;41(6):753-8.

28. Foote CS. Free Radicals in Biology. $3^{\text {rd }}$ ed. New York: Academic Press; 1976.

29. Charles DJ. Antioxidant properties of spices shells and other. London: John Willey; 2013.

30. Kobayashi M, Sakamoto Y. Singlet oxygen quenching ability of astaxanthin esters from the green alga Haematococcus pluvialis. Biotech Lett 1999;21(4):265-9.

31. Beutner S, Bloedorn B, Hoffmann T, Martin HD. Synthetic singlet oxygen quenchers. Methods Enzymol 2000;319:226-41. 